\title{
Pengembangan Media Pembelajaran Interaktif Berbasis Android dan Efek Terhadap Hasil Belajar Peserta Didik Kelas XI IPS SMA
}

\author{
Marina Nur Cahyaningrum ${ }^{1}$, Norida Canda Sakti ${ }^{2}$ \\ marina.17080554013@mhs.unesa.ac.id¹', noridacanda@unesa.ac.id² \\ Pendidikan Ekonomi, Universitas Negeri Surabaya
}

\begin{abstract}
This research was carried out on the basis of the problem because of the little choice of learning media a teacher uses on economics subjects discussing complex APBN and APBD material. The purpose of this research is to determine the feasibility of the media, find out learners' response, and learning outcomes of students after the implementation of android-based interactive learning media. This research adopts the 4D development model which only reaches the development stage. This research was conducted on 20 students of class XI social sciences in the $5^{\text {th }}$ Senior High School Tuban by collecting data using interviews and questionnaires that were analyzed through quantitative and qualitative data analyzed. The result is interactive learning media based on android with the APK format APBN and APBD material. The validation result obtained proper conclusions consisting of material expert $100 \%$, media expert $97,5 \%$, evaluation expert $78,67 \%$, media practicality expert $100 \%$, and media effectiveness $100 \%$. Students resulted in positive responses by $97 \%$ and can encourage learning outcomes with an average Gain Score 0,72 and completeness of classical posttest attain $95 \%$. So, android based interactive learning media can improve student learning outcomes.
\end{abstract}

Keywords: interactive learning media, android based, learning outcomes

\begin{abstract}
Abstrak
Penelitian ini dilaksanakan atas dasar permasalahan karena sedikitnya pilihan media pembelajaran yang digunakan oleh guru pada mata pelajaran ekonomi bahasan materi APBN dan APBD yang kompleks. Tujuan penelitian ini yaitu untuk menentukan kelayakan media, respon peserta didik, dan hasil belajar peserta didik sesudah difungsikannya media pembelajaran interaktif berbasis android. Penelitian ini mengadopsi model pengembangan 4D yang hanya sampai pada tahap pengembangan (develop). Penelitian ini dilaksanakan pada 20 peserta didik kelas XI IPS di SMAN 5 Tuban dengan cara wawancara dan angket yang dianalisis menggunakan analisis data kuantitatif dan kualitatif. Hasil penelitian yaitu media pembelajaran interaktif berbasis android yang berformat APK pada materi APBN dan APBD. Hasil validasi memperoleh simpulan sangat layak yang terdiri dari ahli materi $100 \%$, ahli media $97,5 \%$, ahli evaluasi $78,67 \%$, ahli kepraktisan media $100 \%$, dan ahli efektivitas media 100\%. Peserta didik memberikan respon positif dengan hasil $97 \%$ dan dapat mendorong meningkatnya hasil belajar yang tinggi dengan perolehan nilai rata-rata Gain Score 0,72 dan ketuntasan klasikal posttest mencapai 95\%. Jadi, media pembelajaran interaktif berbasis android mampu meningkatkan hasil belajar.
\end{abstract}

Kata Kunci: media pembelajaran interaktif, berbasis android, hasil belajar

\section{PENDAHULUAN}

IImu pengetahuan dan teknologi yang mengalami kemajuan pesat di era globalisasi telah mempengaruhi berbagai bidang salah satu bidang yang terkena pengaruhnya yaitu bidang pendidikan. Hal ini sejalan dengan Tan et al. (2020) yang menjelaskan bahwa proses pengajaran menggunakan teknologi dapat membantu guru dalam menjelaskan teori dan dapat menarik peserta didik untuk belajar Dalam bidang pendidikan proses pembelajaran di era globalisasi diharuskan untuk mengikuti perkembangan teknologi (Budiman, 2017). Proses pembelajaran menurut Pane \& Dasopang (2017) merupakan suatu kegiatan dua komponen yaitu guru dan peserta didik yang saling terlibat dan saling berhubungan untuk mendapat hasil sesuai dengan tujuan. 


\section{Efektor, Volume 8 Issue 1, 2021, Pages 21 - 33}

Marina Nur Cahyaningrum, Norida Canda Sakti

Kemajuan dalam bidang pendidikan terlihat dari kegiatan belajar mengajar yang saat ini berpusat pada peserta didik yang lebih aktif dan guru tidak lagi menjadi pusat pembelajaran. dalam proses ini guru memiliki peran sebagai fasilitator yang memberikan peserta didik kemudahan belajar agar dapat belajar dengan nyaman serta dapat memberikan arahan bahwa peserta didik diharuskan mencari sumber informasi untuk membangun pengetahuannya sendiri (Nurhamidah, 2018). Dengan adanya kemajuan penggunaan teknologi kegiatan pembelajaran mengalami perkembangan dari tatap muka menjadi pembelajaran online (Lin et al., 2017). Kegiatan pembelajaran yang mengalami perkembangan ini dapat membuat peserta didik menjadi mandiri dalam kegiatan belajar. Didukung pula penelitian yang dilakukan oleh Budiman (2017) bahwa perkembangan IPTEK dalam kegiatan belajar mengajar selain untuk membantu peserta didik dalam belajar juga berperan yang memiliki pengaruh untuk guru dalam pemanfaatan fasilitas untuk memperbanyak kemampuan mengajarnya. Dengan kata lain, dari pesatnya perkembangan teknologi dapat membantu guru untuk melakukan proses pembelajaran yang lebih bervariasi yang ditunjang dengan teknologi untuk mengikuti perkembangan era globalisasi (Delialioğlu \& Alioon, 2014).

Teknologi informasi yang lebih banyak digunakan di era ini adalah smartphone (Amirullah \& Susilo, 2018). Sekarang ini smartphone sudah tidak menjadi barang mewah yang dapat dimiliki oleh kalangan atas saja tetapi smartphone telah menjadi barang primer yang dapat dimiliki oleh semua kalangan dari menengah kebawah hingga menengah atas. Hal ini didukung oleh Hanika (2015) menyatakan bahwa handphone menjadi barang yang dapat dimiliki seluruh kalangan dikarenakan harganya yang terjangkau. Pada tahun 2019, Indonesia berada pada peringkat ke-6 sebagai pengguna smartphone terbesar, dimana sebanyak 73 juta jiwa penduduk Indonesia telah menggunakan smartphone (Herdyanto, 2019).

Saat ini penggunaan smartphone dalam kegiatan pembelajaran di Sekolah Menengah Atas telah menjadi hal yang wajar. Salah satu Sekolah Menengah Atas yang mengijinkan peserta didiknya untuk menggunakan smartphone dalam kegiatan pembelajaran adalah SMAN 5 Tuban. Berdasarkan kegiatan observasi yang dilakukan peneliti di SMAN 5 Tuban hampir seluruh peserta didiknya memiliki smartphone. Berikut ini adalah daftar pengguna smartphone yang berada di kelas XI IPS SMAN 5 Tuban:

Tabel 1. Daftar Pengguna Smartphone Kelas XI IPS

\begin{tabular}{ccccc}
\hline No. & Kelas & $\begin{array}{c}\text { Jumlah Peserta } \\
\text { Didik }\end{array}$ & $\begin{array}{c}\text { Pengguna Sistem } \\
\text { Android }\end{array}$ & $\begin{array}{c}\text { Pengguna } \\
\text { iOS }\end{array}$ \\
\hline 1 & XI IPS 1 & 35 & 35 & - \\
2 & XI IPS 2 & 36 & 30 & 6 \\
\hline \multicolumn{2}{r}{ Jumlah } & 71 & 65 & 6
\end{tabular}

Sumber: diolah peneliti (2021)

Pemilihan media pembelajaran berbasis android dilakukan agar hasil belajar peserta didik maksimal. Hasil belajar adalah suatu perolehan peserta didik dari usaha yang dilakukan dalam menambah pengetahuan, informasi, serta pengalaman dalam kegiatan belajar (Asriningtyas et al., 2018). Hasil belajar peserta didik akan meningkat apabila guru menggunakan media yang tepat, didukung oleh penelitian Widiasih et al. (2018) penggunaan media yang bervariasi dapat mendorong semangat belajar peserta didik dan berpengaruh terhadap hasil belajarnya. Media belajar menjadi 


\section{Efektor, Volume 8 Issue 1, 2021, Pages 21 - 33 \\ Marina Nur Cahyaningrum, Norida Canda Sakti}

menarik apabila dipadukan dengan teknologi salah satunya smartphone, dengan teknologi media dapat menjadi fasilitas penyalur informasi yang dapat mendukung peserta didik belajar dimana dan kapan saja (Kularbphettong et al., 2015). Didukung oleh Naik et al. (2020) menyatakan bahwa selain teknologi digunakan untuk mempermudah komunikasi ternyata teknologi juga dapat digunakan untuk alat peraga dalam pembelajaran untuk meningkatkan hasil belajar dan kualitas belajar peserta didik. Menurut Nurseto (2012) media pembelajaran merupakan sarana untuk menyampaikan pesan maupun informasi belajar yang didesain dengan baik guna memberi bantuan peserta didik mencapai tujuan belajar dan memperlancar proses belajar serta pengoptimalan hasil belajar.

Atas dasar hasil wawancara yang dilakukan dengan guru ekonomi, bahwa dalam kegiatan pembelajaran online pada saat pandemi maupun saat pembelajaran tatap muka guru menggunakan metode konvensional dengan cara menjelaskan dengan memanfaatkan microsoft powerpoint sebagai media untuk presentasi. Powerpoint sebenarnya memiliki banyak kelebihan untuk pembelajaran yaitu mampu mengefektifkan motivasi dan hasil belajar karena dapat memuat konsep abstrak menjadi konkrit melalui visualisasi (Nurhidayati et al., 2019). Kelebihan yang dimiliki powerpoint belum dapat diterapkan dengan baik di SMAN 5 Tuban khususnya pada pembelajaran ekonomi karena pembuatannya yang sederhana tanpa ada desain yang menarik sehingga materi yang diajarkan belum mudah dipahami oleh peserta didik. Media belajar lain yang digunakan oleh guru dan peserta didik yaitu buku paket yang disediakan oleh sekolah. Namun, guru mata pelajaran eknomi mengakui bahwa peserta didik lebih suka menggunakan smartphone untuk belajar dari pada menggunakan buku paket karena smartphone mudah dibawa kemana-mana.

Karena media pembelajaran teks yang dikemas dengan powerpoint dibuat dengan desain yang kurang menarik membuat peserta didik kurang memperhatikan sehingga mengalami kesulitan dalam pemahaman materi. Menurut Kurniawan \& Rohmani (2019) kegiatan belajar menggunakan teknologi smartphone membuat peserta didik lebih tertarik untuk belajar dan mempermudah memahami materi dibandingkan belajar dengan menggunakan buku teks yang membuat peserta didik tidak tertarik untuk belajar. Penelitian yang dilakukan oleh Pratama \& Sakti (2020) menyebutkan bahwa pembelajaran menggunakan powerpoint pada materi APBN dan APBD belum bisa mempermudah peserta didik memahami materi sedangkan pembelajaran menggunakan andorid dapat meningkatkan ketertarikan belajar dan mampu memengaruhi hasil belajar peserta didik. Hal ini didukung oleh Sefriani \& Sepriana (2020) menyatakan bahwa pembelajaran dengan memanfaatkan smartphone dapat memaksimalkan belajar peserta didik dimana saja dan memudahkan peserta didik belajar menggunakan smartphone yang dimilikinya. Karena penggunaan smartphone dalam kegiatan belajar dapat memudahkan peserta didik dalam belajarnya mendorong peneliti untuk mengembangkan aplikasi media pembelajaran interaktif yang dapat dioperasikan di smartphone android sesuai dengan kebutuhan peserta didik.

Media pembelajaran interaktif menurut Dewi et al. (2018) merupakan alat perantara yang digunakan untuk menyampaikan materi dari sumber belajar dengan metode pembelajaran yang memberikan umpan balik terhadap pengguna. Media pembelajaran interaktif merupakan alat peraga mempunyai alat kontrol untuk digunakan pengguna menentukan materi untuk dipelajari (Fadli \& Hakiki, 2020). Media pembelajaran interaktif menjadikan peserta didik lebih efektif dan fleksibel dalam belajar karena peserta didik dapat memilih materi dan dapat mengulang materi tanpa mengikuti urutan materi belajar. Didukung pula penelitian yang dilakukan Wahyono (2019) dengan judul "Pengembangan Media Pembelajaran Ekonomi Interaktif Berbasis Android Sebagai Upaya Peningkatan Aktivitas dan Hasil Belajar Siswa" mengatakan bahwa kegiatan belajar ekonomi di kelas tanpa memfungsikan media 


\section{Efektor, Volume 8 Issue 1, 2021, Pages 21 - 33 \\ Marina Nur Cahyaningrum, Norida Canda Sakti}

pembelajaran interaktif dinyatakan tidak efektif dan kelas yang memfungsikan media pembelajaran interaktif dinyatakan efektif. Penelitian yang dilakukan oleh Muslimin et al. (2017) yang berjudul "MobiEko: Mobile Educational Application For Economics Education" juga mengemukakan bahwa pembelajaran dengan menggunakan mobile application dapat memberikan respon positif dan meningkatkan hasil belajar.

Menurut Tarigan \& Siagian (2015) media pembelajaran interaktif perlu pengembangan dengan menggunakan perangkat lain selain komputer seperti android atau tablet serta perlunya ditambahkan video pembelajaran dan soal latihan yang bervariasi agar memberi kemudahan peserta didik untuk memahami isi materi. Dari fenomena tersebut penting dilakukan pengembangan media pembelajaran interaktif berbasis android pada mata pelajaran ekonomi materi APBN dan APBD dengan memberikan video dan soal latihan beserta umpan baliknya berupa kunci jawaban didalam media pembelajaran interaktif berbasis android.

Dari latar belakang yang telah dipaparkan di atas, perlu dilakukan penelitian pengembangan media dalam materi APBN dan APBD karena seperti halnya yang dijelaskan oleh lbu Wahyu Christiani, S.Pd. selaku guru ekonomi mengatakan bahwa materi APBN dan APBD merupakan salah satu materi yang memerlukan sumber bahasan dan pertemuan yang intens karena materi dirasa kompleks dari pengalaman mengajarnya. Sehingga tujuan dari adanya penelitian ini diantaranya: 1) Menganalisis tingkat kelayakan media pembelajaran interaktif berbasis android, 2) Menganalisis tingkat efektivitas media pembelajaran interaktif berbasis android, 3) Menganalisis kepraktisan media pembelajaran interaktif berbasis android, 4) Menganalisis respon peserta didik terhadap media pembelajaran interaktif berbasis android, 5) Menganalisis perbedaan hasil belajar peserta didik sebelum dan setelah menerapkan media pembelajaran interaktif berbasis android. Penelitian pengembangan diusulkan untuk menciptakan sebuah produk media dengan judul "Pengembangan Media Pembelajaran Interaktif Berbasis Android Terhadap Hasil Belajar Peserta Didik Kelas XI IPS SMAN 5 Tuban”. Diharapkan hasil dari adanya penelitian ini muncul solusi pada media pembelajaran baru berbentuk aplikasi android yang dapat diterapkan dengan tepat.

\section{METODE PENELITIAN}

Peneliti memutuskan untuk menerapkan jenis penelitian dan pengembangan yang biasa disebut dengan Research and Development (R\&D) dengan menerapkan model 4-D yang memiliki 4 tahap yaitu Define (Pendefinisian), Design (Perancangan), Develop (Pengembangan), dan Disseminate (Penyebaran). Model ini dipilih oleh peneliti karena memiliki sistematika yang terstruktur dan jelas pada setiap langkahnya. Pelaksanaan penelitian ini tidak melaksanakan tahap disseminate (penyebaran) karena terbatasnya biaya dan waktu penelitian. Pada penelitian ini, produk yang akan dikembangkan oleh peneliti yaitu media pembelajaran interaktif berbasis android yang memanfaatkan software Android Studio.

Prosedur penelitian dijabarkan secara detail agar lebih mudah mengetahui tahapan yang dilakukan oleh peneliti. Susunan prosedur penelitian dibagi menjadi 4 tahap, yang pertama adalah tahap define (pendefinisian) yang tersusun atas 5 analisis antara lain 1) analisis awal, 2) analisis peserta didik, 3) analisis tugas, 4) analisis konsep, dan 5) perumusan tujuan pembelajaran. Yang kedua adalah tahap design (perancangan) yang terdiri dari 3 langkah yakni 1) penyusunan tes, 2) pemilihan media, dan 3) pemilihan format. Ketiga yaitu tahap develop (pengembangan) yang terdiri dari 1) telaah dan validasi perangkat oleh para ahli, 2) uji coba lapangan terbatas, dan 3) revisi. Yang terakhir adalah tahap disseminate (penyebaran) melakukan penyebaran produk agar dapat dimanfaatkan oleh lebih 
banyak kelas atau lebih banyak sekolah. Namun adanya keterbatasan waktu dan biaya peneliti tidak melaksanakan sampai pada tahap penyebaran.

Penelitian pengembangan ini difokuskan pada 20 peserta didik sebagai jumlah minimal sampel uji coba. Berkaitan dengan hal ini Sadiman (2014) mengemukakan bahwa untuk mewakili target peneliti harus melakukan pengujian media pada 10-20 peserta didik, karena jika data yang diperoleh kurang dari 10 maka belum bisa menggambarkan target populasi dan akan memperoleh informasi kurang bermanfaat dalam evaluasi kelompok terbatas apabila jumlah data lebih dari 20.

Berikut ini merupakan kerangka prosedur model pengembangan 4-D dari Thiagarajan:

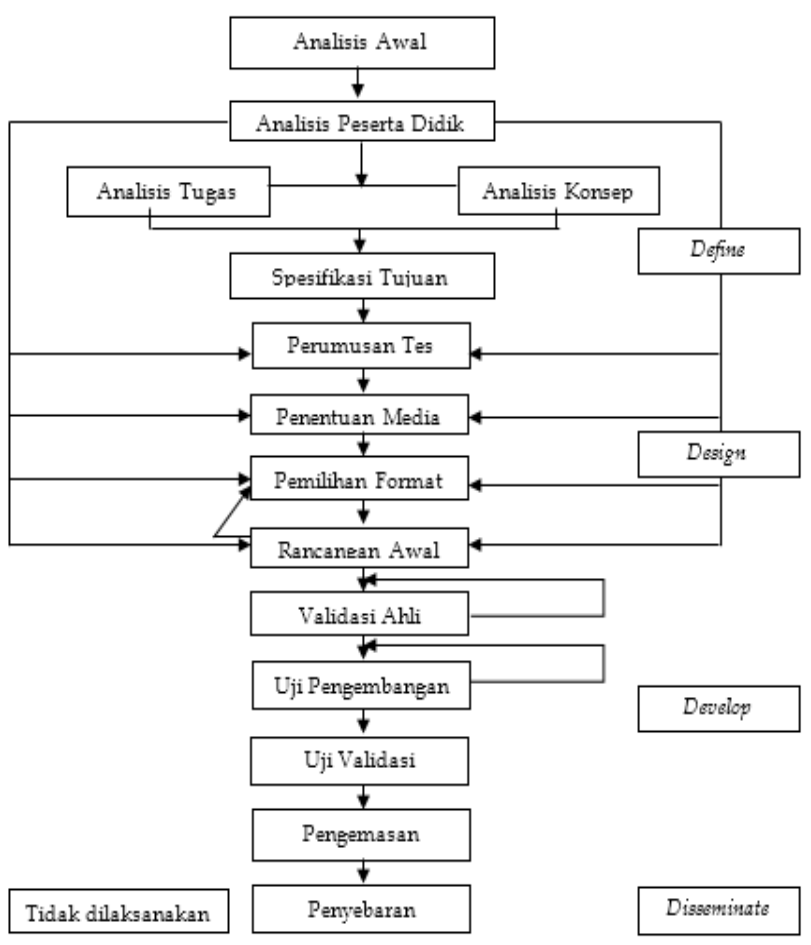

Gambar 1. Prosedur Pengembangan 4D

Pada penelitian ini menerapkan desian uji coba Pre-Experimental design dengan model One Group Pretest-Posttest Design.

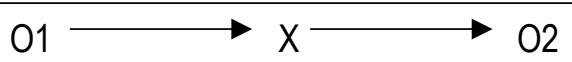

Gambar 2. Desain Uji Coba (Sugiyono, 2016)

Keterangan:

01 : Hasil pretest peserta didik sebelum diberi media pembelajaran

$\mathrm{X} \quad$ : Treatment yang diberikan berupa media pembelajaran interaktif yang dikembangkan peneliti

O2 : Hasil posttest peserta didik sesudah diberi media pembelajaran

Jenis desain One Group Pretest-Posttest dilakukan dengan memilih sampel menggunakan teknik purposive sampling agar sampel yang diambil sesuai dengan kriteria peneliti dan dapat memberi data yang relean dengan tujuan penelitian. Pemilihan dilakukan secara sistematis dengan memilih populasi kelas yang pengguna smartphone android lebih dominan yaitu di kelas XI IPS 1 SMAN 5 Tuban. 
Teknik pengumpulan data menggunakan instrumen antara lain 1) lembar wawancara, 2) lembar telaah dan validasi materi, media, evaluasi, efektivitas, dan kepraktisan media, 3) lembar angket respon peserta didik, dan 4) lembar soal pretest dan posttest.

Teknik analisis data pada penelitian ini menggunakan metode deskriptif kualitatif dan deskriptif kuantitatif. Pada metode deskriptif kualitatif tahap yang dilakukan yaitu mengumpulkan data, mereduksi, dan menyajikan data. Sedangkan pada metode deskriptif kuantitatif prosedur yang dilakukan yaitu menganalisis data angket yang diperloeh dari validator ahli dengan skala likert, data respon peserta didik dengan skala guttman yang diolah menggunakan microsoft excel untuk mengetahui tingkat kelayakan, kepraktisan, dan efektivitas media yang dijelaskan pada tabel berikut:

Tabel 2. Kriteria Kelayakan Media Pembelajaran

\begin{tabular}{cc}
\hline Persentase & Kriteria \\
\hline $0 \%-20 \%$ & Sangat tidak layak \\
$21 \%-40 \%$ & Tidak layak \\
$41 \%-60 \%$ & Cukup layak \\
$61 \%-80 \%$ & Layak \\
$81 \%-100 \%$ & Sangat Layak
\end{tabular}

Sumber: (Sugiyono, 2016)

Analisis hasil belajar melalui soal pretest dan posttest dianalisis menggunakan gain score atau $\mathrm{N}$-Gain dengan kriteria $\geq 0,3$ maka media pembelajaran interaktif dapat dikatakan sebagai media yang layak digunakan dalam meningkatkan hasil belajar peserta didik.

Spesifikasi produk media yang dikembangkan yakni: 1) media pembelajaran yang dikembangkan berbentuk media aplikasi yang dapat diakses pada smartphone android, 2) ukuran media pembelajaran interaktif sebesar 27MB, 3) media pembelajaran interaktif memiliki 8 menu antara lain pentunjuk penggunaan, kompetensi dasar dan indikator, peta konsep, materi, latihan soal, glosarium, daftar rujukan, profil pengembang, 4) media pembelajaran interaktif berbasis android memiliki nama "Mediko".

\section{HASIL DAN PEMBAHASAN}

Hasil

Hasil penelitian dan pengembangan ini yang terdiri dari tiga tahap antara lain define (pendefinisian), design (perancangan), dan develop (pengembangan). Pada tahap pertama yaitu define (pendefinisian) terdiri dari analisis awal yang diketahui pada saat observasi yaitu masih sedikitnya pilihan media pembelajaran yang dimanfaatkan guru sehingga guru menggunakan media pembalajaran presentasi dengan memanfaatkan powerpoint pada materi yang kompleks dan cenderung kurang mendorong semangat belajar peserta didik serta dalam proses belajar guru lebih sering menerapkan metode konvensional yang membuat peserta didik kurang aktif. Selanjutnya, pada analisis peserta didik terdapat $91 \%$ peserta didik dengan kepemilikan smartphone android dan $9 \%$ peserta didik dengan kepemilikan iPhone, serta tidak ada peserta didik yang memiliki smartphone merek lain. Dalam analisis peserta didik peneliti juga memperoleh informasi dari guru ekonomi melalui wawancara bahwa minat peserta didik untuk mengerjakan tugas serta mempelajari materi yang ada di buku paket masih kurang dan peserta didik akan lebih tertarik jika tugas dan materi pembelajaran dapat diakses melalui smartphone. Pada analisis tugas berisi penugasan untuk peserta didik dan peneliti telah menentukan kisi-kisi tugas. Adapun dalam analisis konsep dan perumusan tujuan pembelajaran peneliti memperoleh 12 indikator kompetensi dan rumusan tujuan pembelajaran dari hasil identifikasi KD 3.6 APBN dan APBD dalam pembangunan. 
Tahapan yang kedua adalah design (perancangan) yaitu merancang media pembalajaran bagaimana cara membuatnya sesuai kebutuhan. Rancangan yang diperoleh berupa media pembelajaran yang dapat dioperasikan melalui smartphone android dengan konten materi APBN dan APBD. Dalam tahap ini peneliti melakukan kegiatan yaitu penyusunan tes yang bertujuan untuk menyusun tes evaluasi peserta didik, memilih software yang digunakan untuk mengembangkan media yakni menggunakan Android Studio, serta memilih format yang berisi mengenai penentuan sumber materi yang relevan. Materi yang disampaikan dalam media berbentuk teks narasi dengan tema warna biru muda dan disertai dengan video pembelajaran berupa ringkasan materi. Komponen yang terdapat dalam media yaitu 1) halaman loading screen berisi logo, 2) halaman welcome screen berisi logo dan judul materi, 3) halaman login untuk membedakan user, 4) halaman menu utama terdapat menu-menu diantaranya petunjuk, KD dan indikator, peta konsep, materi, latihan soal, glosarium, daftar rujukan, dam profil, 5) Menu materi berisi pilihan materi dan video pembelajaran.

Tahap selajutnya yaitu develop (pengembangan) dengan media yang telah mengalami pengembangan dengan penambahan 2 menu utama dan 1 submenu. 2 menu utama yakni menu glosarium dan daftar rujukan serta 1 submenu yaitu video pembelajaran. Pengoptimalan media pembelajaran dengan format aplikasi android terdapat pada menu latihan soal yang berisi soal pilihan ganda yang dapat diketahui nilai serta kunci jawabannya. Pada proses pengembangan juga dilakukan penilaian oleh para ahli pada masing-masing bidang media, materi, evaluasi, efektivitas, dan kepraktisan media yang berupa komentar untuk dijadikan acuan penyempurnaan media yang dikembangkan. Dari uji media yang dilakukan oleh dosen ahli bidang media diperoleh komentar untuk menghilangkan animasi yang tidak terkait dengan materi dan memperbesar ukuran tombol icon pada menu materi. Berikut merupakan tampilan media sebelum dan setelah revisi oleh satu ahli media yaitu Bapak Dr. Fajar Arianto, M.Pd. selaku dosen Teknologi Pendidikan Universitas Negeri Surabaya:

Tabel 3. Tampilan Menu Sebelum dan Setelah Revisi

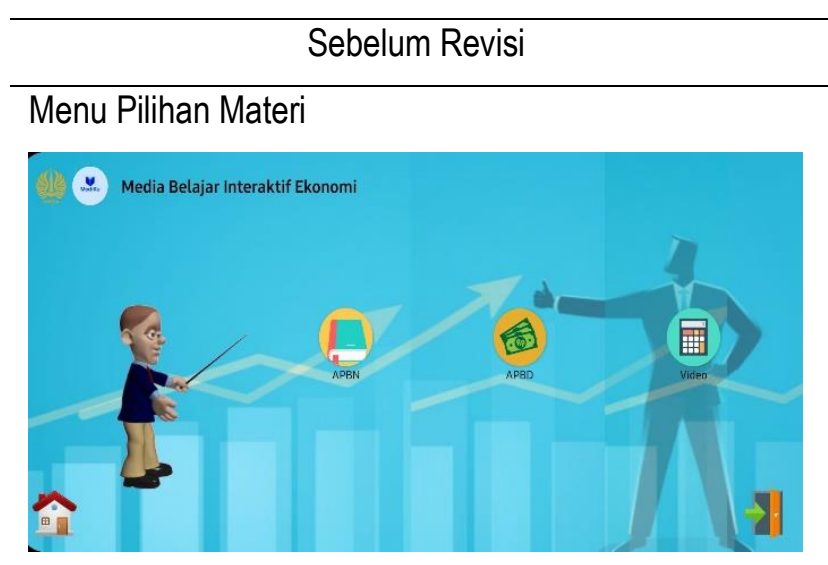

Menu Materi

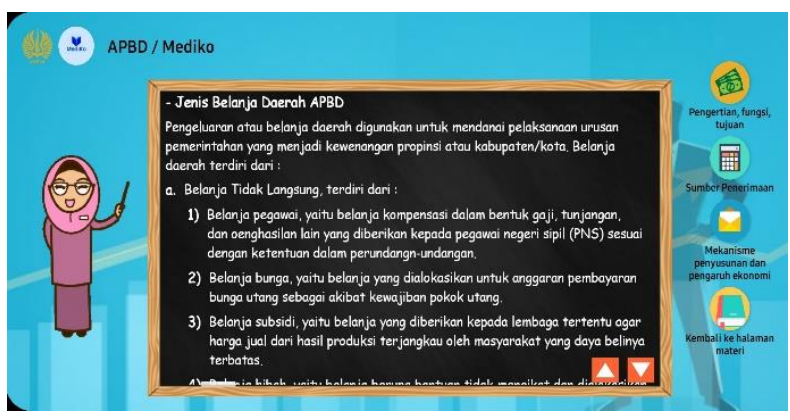

Sesudah Revisi Menu Pilihan Materi

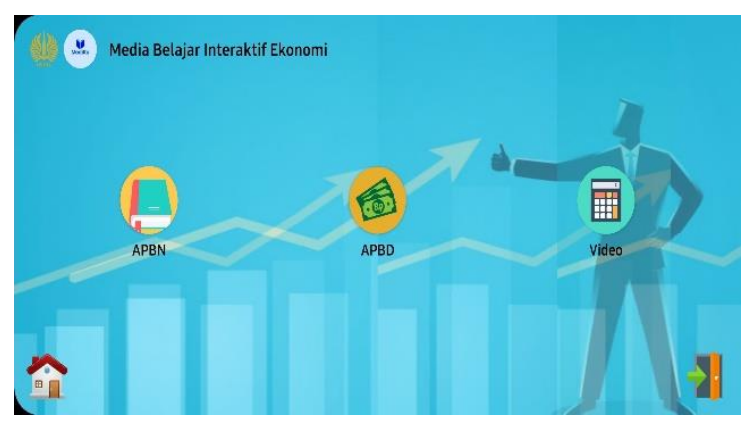

Menu Materi

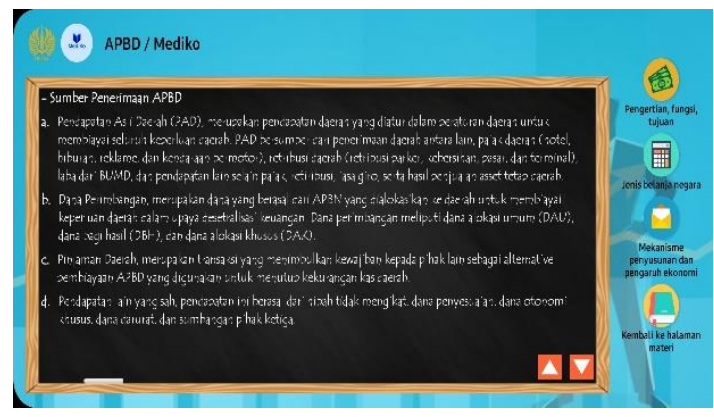

Sedangkan untuk ahli materi yang dilakukan oleh satu dosen ahli yaitu Bapak Dr. Norida Canda Sakti, M.Si. selaku dosen Pendidikan Ekonomi Universitas Negeri Surabaya tidak ada saran perbaikan, dan 
pada ahli evaluasi yang dilakukan oleh satu dosen yaitu Ibu Retno Mustika Dewi, S.Pd., M.Pd. selaku dosen Pendidikan Ekonomi Universitas Negeri Surabaya menyarankan agar memperbaiki kalimat pada beberapa pertanyaan dan menyesuaikan dengan tingkat kognitifnya.

Setelah melakukan revisi dan telah dinyatakan layak oleh para ahli, hasil tersebut akan dikombinasi dengan uji coba terbatas pada 20 peserta didik yang sedang mempelajari materi APBN dan APBD di sekolah. Uji coba terbatas bertujuan untuk melihat respon peserta didik melalui angket serta hasil belajar dari nilai pretest dan posttest setelah diterapkannya media pembelajaran yang dikembangkan peneliti sebagai media pembelajaran.

\section{Pembahasan}

\section{Kelayakan Media Pembelajaran Interaktif Berbasis Android}

Kelayakan media pembelajaran yang dikembangkan oleh peneliti didapatkan melalui penilaian yang telah dilakukan oleh para ahli validasi media, materi, dan evaluasi. Berikut merupakan hasil validasi media untuk mengetahui tingkat kelayakan media:

Tabel 4. Hasil Validasi Media

\begin{tabular}{cccc}
\hline No. & Aspek yang Dinilai & Persentase & Kriteria Kelayakan \\
\hline 1 & Kualitas Teknis & $98 \%$ & Sangat Layak \\
2 & Kualitas Instruksional & $96 \%$ & Sangat Layak \\
\hline & Total Persentase & $194 \%$ & - \\
& Rata-rata seluruhnya & $97 \%$ & Sangat Layak \\
\hline
\end{tabular}

Sumber: data diolah oleh peneliti (2021)

Dari tabel 2 persentase rata-rata dari seluruh aspek penilaian sebesar $97 \%$ dan dinyatakan media sangat layak diterapkan sebagai media pembelajaran. Penelitian yang mendukung adalah Neni \& Rosita (2019) yang memperoleh persentase validasi media sebesar $91,66 \%$ pada kriteria sangat layak.

Dari hasil validasi ahli materi diperoleh sebagai berikut:

Tabel 5. Hasil Validasi Materi

\begin{tabular}{cccc}
\hline No. & \multicolumn{1}{c}{ Aspek yang Dinilai } & Persentase & Kriteria Kelayakan \\
\hline 1 & Kualitas Isi/Tujuan & $100 \%$ & Sangat Layak \\
2 & Kualitas Instruksional & $100 \%$ & Sangat Layak \\
3 & Kualitas Teknis & $100 \%$ & Sangat Layak \\
\hline & Total Persentase & $300 \%$ & - \\
& Rata-rata seluruhnya & $100 \%$ & Sangat Layak \\
\hline
\end{tabular}

Sumber: data diolah oleh peneliti (2021)

Berdasrakan tabel 3 menunjukkan rata-rata persentase dari seluruh aspek penilaian sebesar $100 \%$ dan termasuk kedalam kriteria sangat layak. Hal ini didukung oleh peneilitian Neni \& Rosita (2019) perolehan persentase validasi materi sebesar $88,75 \%$ pada kategori sangat layak.

Diperoleh juga tingkat kelayakan soal evaluasi, berikut merupakan hasil validasi evaluasi:

Tabel 6. Hasil Validasi Evaluasi

\begin{tabular}{clcc}
\hline No. & \multicolumn{1}{c}{ Aspek yang Dinilai } & Persentase & Kriteria Kelayakan \\
\hline 1 & Materi & $76,75 \%$ & Layak \\
2 & Konstruksi & $79,25 \%$ & Layak \\
3 & Bahasa & $80 \%$ & Layak \\
\hline \multicolumn{2}{c}{ Total Persentase } & $236 \%$ & -
\end{tabular}




\begin{tabular}{ccc} 
Rata-rata seluruhnya & $78,67 \%$ & Layak \\
\hline Sumber: data diolah oleh peneliti (2021) &
\end{tabular}

Pada tabel 4 menunjukkan persentase rata-rata dari keseluruhan aspek sebesar $78,67 \%$ dan termasuk kedalam kriteria layak. Dari penilaian ahli pada masing-masing bidang dapat disimpulkan bahwa media pembelajaran interaktif berbasis android sangat layak diterapkan sebagai media pembelajaran ekonomi di kelas XI IPS.

\section{Efektivitas Penggunaan Media Pembelajaran Interaktif Berbasis Android}

Efektivitas media pembelajaran yang dikembangkan oleh peneliti didapatkan dari hasil validasi oleh dosen ahli. Berikut merupakan hasil validasi efektivitas media:

Tabel 7. Hasil Validasi Efektivitas Media

\begin{tabular}{cccc}
\hline No. & \multicolumn{1}{c}{ Aspek yang Dinilai } & Persentase & Kriteria \\
\hline 1 & Minat dan Motivasi & $100 \%$ & Sangat Efektif \\
2 & Fungsi Media Pembelajaran & $100 \%$ & Sangat Efektif \\
3 & Reliabilitas & $100 \%$ & Sangat Efektif \\
\hline & Total Persentase & $300 \%$ & - \\
& Rata-rata seluruhnya & $100 \%$ & Sangat Efektif \\
\hline
\end{tabular}

Sumber: data diolah oleh peneliti (2021)

Dari tabel 5 menunjukkan persentase rata-rata dari keseluruhan aspek yang dinilai sebesar $100 \%$. Hal ini membuat media pembelajaran yang dikembangkan sudah memenuhi syarat efektif untuk diterapkan dalam proses pembelajaran dengan kriteria efektivitas $\geq 61 \%$.

\section{Kepraktisan media pembelajaran interaktif berbasis android}

Kepraktisan media pembelajaran yang dikembangkan oleh peneliti dilihat dari data yang diperoleh dari penilaian ahli yaitu:

Tabel 8. Hasil Validasi Praktikalitas

\begin{tabular}{clcc}
\hline No. & \multicolumn{1}{c}{ Aspek yang Dinilai } & Persentase & Kriteria \\
\hline 1 & Manfaat & $100 \%$ & Sangat Praktis \\
2 & Penggunaan & $100 \%$ & Sangat Praktis \\
\hline & Total Persentase & $200 \%$ & - \\
& Rata-rata seluruhnya & $100 \%$ & Sangat Praktis \\
\hline
\end{tabular}

Sumber: data diolah oleh peneliti (2021)

Dari tabel 6 dapat diketahui bahwa produk media pembelajaran interaktif berbasis android sudah sangat praktis diterapkan dalam kegiatan pembelajaran. Hal ini ditunjukkan dari rata-rata persentase seluruh aspek sebesar 100\% yang dapat diartikan media sangat praktis digunakan.

\section{Respon Peserta Didik Terhadap Media Pembelajaran Interaktif Berbasis Android}

Sesuai dengan data angket respon peserta didik yang diperoleh dari uji coba terbatas, peneliti memperoleh penjelasan bahwa respon peserta didik terhadap media pembelajaran interaktif berbasis android beragam. Data yang diperoleh menunjukkan bahwa sebanyak 275 jawaban "iya" dan sebanyak 5 jawaban "tidak" dari total 280 jawaban dengan 14 pernyataan. Sesuai dengan hasil angket tersebut diperoleh persentase rata-rata dari seluruh aspek penilaian sebesar 97,5\% yang meliputi aspek kemudahan diperoleh persentase sebesar $100 \%$, aspek kemenarikan sebesar $100 \%$, aspek proses 


\section{Efektor, Volume 8 Issue 1, 2021, Pages 21 - 33}

Marina Nur Cahyaningrum, Norida Canda Sakti

belajar peserta didik sebesar 92,5\%, dan aspek kualitas media sebesar 97,5\%. Dari hasil tersebut, respon peserta didik yang didapatkan dinyatakan positif dan sangat baik.

\section{Perbedaan Hasil Belajar Peserta Didik Sebelum Dan Setelah Menggunakan Media Pembelajaran Interaktif Berbasis Android}

Analisis hasil belajar dilakukan guna mengetahui perubahan nilai peserta didik terhadap materi yang diajarkan dengan memfungsikan produk media hasil pengembangan. Pemberian soal pretest dan posttest kepada peserta didik dilakukan untuk menganalisis perubahan hasil belajar. Nilai pretest diperoleh saat sebelum peserta didik diberikan materi dengan memfungsikan media pembelajaran yang dikembangkan. Dan nilai posttest diperoleh setelah peserta didik diberikan materi dengan memfungsikan media pembelajaran yang dikembangkan. Untuk mengetahui peningkatan hasil belajar peneliti melakukan uji lapangan terbatas dengan memberikan soal pretest dan posttest yang sudah divalidasi pada 20 peserta didik kelas XI IPS 1 SMAN 5 Tuban. Berikut merupakan penghitungan dengan rumus gain score untuk mengetahui besarnya peningkatan hasil belajar:

Tabel 9. Rekapitulasi Analisis Hasil Belajar dengan Gain Score

\begin{tabular}{cccc}
\hline \multicolumn{4}{c}{ Tes } \\
\hline Rata-rata Nilai Pretest & Rata-rata Nilai Posttest & Gain Score & Kategori \\
\hline 62 & 89,75 & 0,73 & Tinggi \\
\hline
\end{tabular}

Sumber: data diolah oleh peneliti (2021)

Dari tabel 7 rata-rata pretest adalah 62 dan posttest adalah 89,75. Peningkatan hasil belajar dengan rumus gain score diperoleh angka 0,73 dengan kategori tinggi. Perolehan tersebut dirinci sebanyak 6 peserta didik memiliki interval gain score $0,3 \leq \mathrm{g}>0,7$ dan sebanyak 14 peserta didik memiliki interval gain score $\geq 0,7$. Hasil peningkatan belajar peserta didik yang tinggi karena adanya dampak penggunaan media pembalajaran yang baru. Hal ini didukung penelitian yang dilakukan oleh Setyaningsih \& Sakti (2020) menunjukkan nilai gain score kelas eksperimen mengalami peningkatan hasil belajar materi kebijakan moneter dari pada kelas kontrol.

Dari hasil perhitungan ketuntasan belajar klasikal sebelum diterapkan media pembelajaran interaktif berbasis android belum tercapai dengan diperoleh persentase ketuntasan klasikal $25 \%$ sedangkan ketuntasan belajar klasikal setelah diterapkan media pembelajaran interaktif berbasis android sudah tercapai dengan perolehan persentase ketuntasan klasikal 95\% karena persentase ketuntasan klasikal $\geq 75 \%$. Jadi hasil yang diperoleh merupakan data yang tergolong pada kriteria tuntas sesuai dengan penelitian Candrawati (2020) yang memperoleh nilai $\geq 85 \%$ sudah mencapai kriteria ketuntasan klasikal dengan kategori tuntas.

Atas dasar perhitungan rumus gain score dan ketuntasan klasikal membuat penelti mengetahui selisih hasil belajar antara pretest dan posttest meningkat. Jadi, diperoleh kesimpulan bahwa media pembelajaran interaktif berbasis android yang dikembangkan peniliti efektif diterapkan sebagai media pembelajaran.

\section{SIMPULAN}

Berdasarkan hasil penelitian pengembangan yang telah diteliti, peneliti memperoleh kesimpulan: 1) Media pembelajaran berupa media interaktif berbentuk aplikasi android yang dapat dioperasikan dengan cara online di smartphone android minimal versi KitKat (Android 4.4), 2) Hasil 


\section{Efektor, Volume 8 Issue 1, 2021, Pages 21 - 33 \\ Marina Nur Cahyaningrum, Norida Canda Sakti}

validasi ahli media, materi, evaluasi, kepraktisan media, dan efektivitas media menyatakan bahwa media pembelajaran interaktif berbasis android dinyatakan sangat layak digunakan dalam pembelajaran sebagai penunjang bahan ajar dengan persentase kelayakan sebesar 95\%, 3) Hasil angket respon peserta didik menyatakan bahwa media pembelajaran interaktif berbasis android yang dikembangkan memperoleh respon yang positif dari peserta didik dan memperoleh kategori sangat layak dengan ratarata persentase sebesar $97 \%$ dari 20 peserta didik yang berstatus sebagai subjek uji coba, 4) Media pembelajaran interaktif berbasis android berdasarkan perhitungan gain score dapat mendorong peningkatan hasil belajar peserta didik kelas XI IPS 1 SMAN 5 Tuban dan ketuntasan klasikal tercapai sehingga media efektif untuk digunakan.

\section{DAFTAR RUJUKAN}

Amirullah, G., \& Susilo. (2018). Pengembangan Media Pembelajaran Interaktif Pada Konsep Monera Berbasis Smartphone Android. WACANA AKADEMIKA: Majalah IImiah Kependidikan, 2(1), 3847. https://doi.org/10.30738/wa.v2i1.2555

Asriningtyas, A. N., Kristin, F., \& Anugraheni, I. (2018). Penerapan Model Pembelajaran Problem Based Learning Untuk Meningkatkan Kemampuan Berpikir Kritis dan Hasil Belajar Matematika Siswa Kelas 4 SD. Jurnal Karya Pendidikan Matematika, 5(1). https://doi.org/https://doi.org/10.26714/jkpm.5.1.2018.23-32

Budiman, H. (2017). Peran Teknologi Informasi Dan Komunikasi Dalam Pendidikan. Al-Tadzkiyyah: Jurnal Pendidikan Islam, 8(I), 31-43. https://doi.org/https://doi.org/10.24042/atjpi.v8i1.2095

Candrawati, E. (2020). Penerapan Model Direct Intruction Untuk Meningkatkan Hasil Belajar Biologi. Jurnal Educatio FKIP UNMA, 6(1), 140-146. https://doi.org/10.31949/educatio.v6i1.287

Delialioğlu, Ö., \& Alioon, Y. (2014). Student preferences for m-learning application characteristics. Proceedings of the 10th International Conference on Mobile Learning 2014, 59-65. eric.ed.gov

Dewi, N., Murtinugraha, R. E., \& Arthur, R. (2018). Pengembangan Media Pembelajaran Interaktif Pada Mata Kuliah Teori Dan Praktik Plambing Di Program Studi S1 Pvkb Unj. Jurnal PenSil, 7(2), 95104. https://doi.org/10.21009/pensil.7.2.6

Fadli, R., \& Hakiki, M. (2020). Validitas media pembelajaran interaktif berbasis android pada mata pelajaran komputer dan jaringan dasar di sekolah menengah kejuruan. Jurnal Inovasi Pendidikan Dan Teknologi Informasi, 01(01), 9-15.

Hanika, I. M. (2015). Fenomena Phubbing di Era Milenia. Interkasi:Jurnal IImu Komunikasi, 4(1), 42-51. https://doi.org/https://doi.org/10.14710/interaksi.4.1.42-51

Herdyanto, A. (2019). 10 Negara Ini Punya Jumlah Pengguna Smartphone Terbanyak di Dunia! Idntimes. https://www.idntimes.com/tech/gadget/abraham-herdyanto/negara-dengan-jumlahpengguna-smartphome-terbesar/full

Kularbphettong, K., Putglan, R., Tachpetpaiboon, N., Tongsiri, C., \& Roonrakwit, P. (2015). Developing of mLearning for Discrete Mathematics Based on Android Platform. Procedia - Social and Behavioral Sciences, 197, 793-796. https://doi.org/10.1016/j.sbspro.2015.07.184

Kurniawan, M. F. T., \& Rohmani, L. (2019). Pengembangan Media Pembelajaran Interaktif Berbasis Aplikasi Android Untuk Meningkatkan Hasil Belajar Kewirausahaan. Jurnal Pendidikan Ekonomi, 12(1), 72-77. https://doi.org/https://dx.doi.org/10.17977/UM014v12i12019p072

Lin, M. H., Chen, H. C., \& Liu, K. S. (2017). A study of the effects of digital learning on learning motivation and learning outcome. Eurasia Journal of Mathematics, Science and Technology 
Education, 13(7), 3553-3564. https://doi.org/10.12973/eurasia.2017.00744a

Muslimin, M. S., Nordin, N. M., Mansor, A. Z., Hashim, H., \& Yunos, M. (2017). Chapter 29 MobiEko: Mobile Educational Application For Economics Education. Malaysian Journal of Learning and Instruction, 2, 131-135. https://doi.org/10.32890/mjli.2017.7804

Naik, G., Chitre, C., Bhalla, M., \& Rajan, J. (2020). Impact of use of technology on student learning outcomes: Evidence from a large-scale experiment in India. World Development, 127, 104736. https://doi.org/10.1016/j.worlddev.2019.104736

Neni, W., \& Rosita, F. A. D. (2019). Pengembangan Multimedia Interaktif Berbasis Android Pada Materi Kehidupan Sosial Masyarakat Indonesia. Sejarah Dan Budaya Jurnal Sejarah Budaya Dan Pengajarannya, 13(1), 34-41. https://doi.org/10.17977/um020v13i12019p034

Nurhamidah, I. (2018). Problematika Kompetensi Pedagogi Guru Terhadap Karakteristik Peserta Didik. Jurnal Teori Dan Praksis Pembelajaran IPS, 3(1), 27-38. https://doi.org/http://dx.doi.org/10.17977/um022v3i12018p027 PROBLEMATIKA

Nurhidayati, Asrori, I., Ahsanuddin, \& Dariyadi, M. W. (2019). Pembuatan Media Pembelajaran Berbasis Powerpoint Dan Pemanfaatan Aplikasi Android Untuk Guru Bahasa Arab. Jurnal KARINOV, 2(3). https://doi.org/https://doi.org/10.17977/um045v2i3p181-184

Nurseto, T. (2012). Membuat Media Pembelajaran yang Menarik. Jurnal Ekonomi Dan Pendidikan, 8(1), 19-35. https://doi.org/10.21831/jep.v8i1.706

Pane, A., \& Dasopang, M. D. (2017). Belajar Dan Pembelajaran. FITRAH:Jurnal Kajian IImu-IImu Keislaman, 3(2), 333. https://doi.org/10.24952/fitrah.v3i2.945

Pratama, D. P. A., \& Sakti, N. C. (2020). Pengembangan Media Pembelajaran Handout Digital Berbasis Android. Jurna Pendidikan Ekonomi Undiksha, 12(1). https://doi.org/http://dx.doi.org/10.23887/jjpe.v12i1.25327

Sadiman, A. S. (2014). Media Pendidikan. Rajawali Pers.

Sefriani, R., \& Sepriana, R. (2020). Pengembangan Media E-Learning Berbasis Schoology Pada Pembelajaran Kurikulum Pendidikan Teknologi dan Kejuruan. EDUKATIF Jurnal IImu Pendidikan, 2(1). https://doi.org/https://doi.org/10.31004/edukatif.v2i1.76

Setyaningsih, A., \& Sakti, N. C. (2020). Pengembangan Media Pembelajaran E-Comic pada Materi Kebijakan Moneter dan Fiskal di Kelas XI IPS 1 MAN 1 Mojokerto Anis Setyaningsih Norida Canda Sakti. 8(1). https://doi.org/https://doi.org/10.26740/jupe.v8n1.p1-6

Sugiyono. (2016). Metode Penelitian dan Pengembangan (Research and Development/R\&D). Alfabeta. https://doi.org/https://doi.org.10.1016/j.drudis.2010.11.005

Tan, S., Wijaya, T. T., Zou, L., \& Hermita, N. (2020). Proving the Formula for the Area of a Circle using Hawgent Dynamic Mathematics Software. Journal of Physics: Conference Series, 1655(1). https://doi.org/10.1088/1742-6596/1655/1/012052

Tarigan, D., \& Siagian, S. (2015). Pengembangan Media Pembelajaran Interaktif Pada Pembelajaran Ekonomi. Jurnal Teknologi Informasi \& Komunikasi Dalam Pendidikan, 2(2), 187-200. https://doi.org/10.24114/jtikp.v2i2.3295

Wahyono, H. N. (2019). Pengembangan Media Pembelajaran Ekonomi Interaktif Berbasis Android Sebagai Upaya Peningkatan Aktivitas dan Hasil Belajar Siswa. Gulawentah:Jurnal Studi Sosial, 4(2), 74-77. https://doi.org/10.25273/gulawentah.v4i2.5522

Widiasih, R., Widodo, J., \& Kartini, T. (2018). Pengaruh Penggunaan Media Bervariasi Dan Motivasi 
Efektor, Volume 8 Issue 1, 2021, Pages 21 - 33

Marina Nur Cahyaningrum, Norida Canda Sakti

Belajar Terhadap Hasil Belajar Mata Pelajaran Ekonomi Siswa Kelas Xi Ips Sma Negeri 2 Jember Tahun Pelajaran 2016/2017. Jurnal Pendidikan Ekonomi: Jurnal IImiah IImu Pendidikan, IImu Ekonomi Dan IImu Sosial, 11(2), 103. https://doi.org/10.19184/jpe.v11i2.6454 